\title{
Photocatalytic Degradation of the 2,4-Dichlorophenoxyacetic Acid Herbicide using Supported Iridium Materials
}

\section{Degradación fotocatalítica del herbicida ácido 2,4-diclorofenoxiacético empleando materiales de iridio soportado}

\author{
Claudia Patricia Castañeda Martínez ${ }^{1}$, Ignacio Alfonso Alvarado Ortega ${ }^{2}$, Hugo Alfonso Rojas Sarmiento ${ }^{3}$, \\ Francisco Javier Tzompantzi ${ }^{4}$ y José Ricardo Gómez Romero ${ }^{5}$
}

\begin{abstract}
In this work, the effect of the addition of iridium on $\mathrm{TiO}_{2}$ and $\mathrm{Nb}_{2} \mathrm{O}_{5}$ supports obtained by wet impregnation method was evaluated in the photocatalytic degradation of 2,4-dichlorophenoxiacetic acid under UV irradiation. The synthetized materials were analyzed by different techniques in order to determinate their physicochemical properties. In general, it was observed that the addition of iridium modifies the surface area, band gap energy and it enhances the crystallinity of the materials. Besides, an increase in the photoactivity in the degradation of the herbicide was evidenced using the materials modified. However, the $\mathrm{Ir} / \mathrm{TiO}_{2} \mathrm{photocatalyst}$ possess the best photocatalytic behavior toward the degradation and possible mineralization of the herbicide. The improved performance of the photocatalyst could be argued by the role of the iridium particles as electron collectors favoring the effective separation of the charge carriers and, as consequence, increasing the degradation of the molecule.
\end{abstract}

Keywords: 2,4-diclorophenoxyacetic acid, Iridium, $\mathrm{Nb}_{2} \mathrm{O}_{5}$, Photocatalysis, photodegradation, $\mathrm{TiO}_{2}$

\section{Resumen}

En este trabajo se evaluó el efecto de la adición de iridio sobre soportes de $\mathrm{TiO}_{2}$ y $\mathrm{Nb}_{2} \mathrm{O}_{5}$ obtenidos por el método de impregnación húmeda en la degradación fotocatalítica del ácido 2,4-diclorofenoxiacético bajo irradiación UV. Los materiales sintetizados fueron analizados mediante diferentes técnicas para determinar sus propiedades fisicoquímicas. En general, se observó que la adición de iridio modifica el área superficial, la energía de banda prohibida y mejora la cristalinidad de los materiales. Además, se evidenció un aumento de la fotoactividad en la degradación del herbicida utilizando los materiales modificados. Sin embargo, el fotocatalizador $\mathrm{Ir} / \mathrm{TiO}_{2}$ presentó el mejor comportamiento fotocatalítico hacia la degradación y posible mineralización del herbicida. El rendimiento mejorado del fotocatalizador podría argumentarse por el papel de las partículas de iridio como colectores de electrones que favorecen la separación efectiva de los portadores de carga y, como consecuencia, aumenta la degradación de la molécula.

Palabras clave: ácido 2,4-diclorofenoxiacético, Fotodegradación, Fotocatálisis, Iridio, $\mathrm{Nb}_{2} \mathrm{O}_{5}, \mathrm{TiO}_{2}$

Recepción: 28-oct-2020

Aceptación: 10-dic-2020

\footnotetext{
${ }^{1}$ Ph.D. Escuela de Ciencias Químicas. Facultad de Ciencias. Universidad Pedagógica y Tecnológica de Colombia. Autor de correspondencia: claudia.castaneda@uptc.edu.co

${ }^{2}$ Químico, Escuela de Ciencias Químicas. Facultad de Ciencias. Universidad Pedagógica y Tecnológica de Colombia.

${ }^{3} \mathrm{Ph} . D$. Escuela de Ciencias Químicas. Facultad de Ciencias. Universidad Pedagógica y Tecnológica de Colombia.

${ }^{4} \mathrm{Ph} . \mathrm{D}$. Departamento de Química. Universidad Autónoma Metropolitana.

${ }^{5}$ Ph.D. Departamento de Química. Universidad Autónoma Metropolitana.
} 


\section{Introducción}

Nowadays, one of the main challenges facing the scientific community is oriented to offer solutions to environmental problems by the applications of strategies based in the fulfilment of the green chemistry principles. In this sense, the heterogeneous photocatalysis is considered as a friendly and viable methodology to degradation of different pollutants soluble in water such as phenol compounds [1-3], dyes [4-6] and pesticides [7, 8]. In relation to the latter, the pesticides such as fungicides, insecticides and herbicides are recognized by their frequent use in the agriculture activities for the control and elimination of pests, however, the problem lies in the improper process for the disposal of the wastewaters, which constitutes an important concern considering their toxic nature and the resistance of the biodegradation processes.

In this context, 2,4-dicholorophenoxiacetic acid (2,4-D) is the herbicide most used among chlorophenoxiacetic compounds and it is used mainly to elimination of weeds in grain, corn and grassland [9]; however, the prolonged exposition to this compound could generate important effects in human health and in aquatic life [10]. It is important to mention that the World Health Organization established a maximum concentration of 2,4-D in drinking water equal to $70 \mathrm{ppb}$ [11]. In order to achieve its effective treatment, several strategies have been tested including: electrocoagulation [12], biological degradation [13], catalytic ozonation [14], adsorption [15] and photocatalysis [16].

Generally, the application of the heterogeneous photocatalysis considers the use of a semiconductor material that includes characteristic such as: chemical and biological inertia, nontoxicity, stability to the photocorrosion processes and photoactivity under UV or visible irradiation [17]. Among the semiconductors more used in photocatalysis, titanium dioxide $\left(\mathrm{TiO}_{2}\right)$ occupies the first places, due to its adequate physicochemical properties for the pollutants degradation [18-20]. However, the photoactivity of the material is affected due to the fast recombination frequency of the charge carriers $\left(e^{-} / h^{+}\right.$pairs $)$. One strategy to reverse this disadvantage consists in the surface addition of noble metals on the semi- conductor. Thus, for example, Adbennouri et al. [7] studied the effect of the content of platinum on $\mathrm{TiO}_{2}$ in the photocatalytic degradation of 2,4-D. The authors evidenced an enhancement in the photoactivity with the increase of metal percentage. This results was explained considering the role of the platinum as electron trap, which a decrease in the recombination process was achieved. Yu et al. [21] fabricated $\mathrm{Au}-\mathrm{Pd} / \mathrm{TiO}_{2}$ nanotubes by photo-deposition method. The photocatalytic properties of the materials were evaluated in the degradation of Malathion under UV irradiation. The authors evidenced a degradation of the pesticide of $98.2 \%$ using bimetallic material and $73.8 \%$ conducing the reaction in presence of unmodified $\mathrm{TiO}_{2}$. Maddila et al. [22] evaluated the degradation and mineralization of the Triclopyr pesticide applying the method of photocatalyzed ozonation in presence of a series of photocatalysts of $\mathrm{Au} / \mathrm{TiO}_{2}$. The results revealed an enhancement in the activity with the increase of the gold load. Thus, in presence of the $2 \% \mathrm{Au} / \mathrm{TiO}_{2}$ material a degradation of the pesticide equal to $100 \%$ was achieved.

Other interesting semiconductor is the niobium pentoxide $\left(\mathrm{Nb}_{2} \mathrm{O}_{5}\right)$, due to its unique physical properties such as chemical stability, high refractive index and high photocatalytic performance [23]. As in the case of the $\mathrm{TiO}_{2}$ semiconductor, the efficiency of the $\mathrm{Nb}_{2} \mathrm{O}_{5}$ material in photocatalytic applications can reduce due to the fast recombination of the charge carriers [24]. This drawback can be solved modifying the material by the doping with nonmetals or metals. These dopants should act as traps of the photogenerated $e^{-} / h^{+}$pairs to improve the photoactivity [25,26].

With this in mind, in this work, $\mathrm{Ir} / \mathrm{TiO}_{2}$ and $\mathrm{Ir} / \mathrm{Nb}_{2} \mathrm{O}_{5}$ materials obtained by wet impregnation method were studied. The textural, structural and optical properties of the materials were analyzed and their photocatalytic properties were evaluated in the photodegradation of 2,4-dichlorophenoxiacetic acid under UV irradiation. For comparison, the photocatalytic behavior of the $\mathrm{TiO}_{2}$ and $\mathrm{Nb}_{2} \mathrm{O}_{5}$ supports also was tested. 


\section{Experimental}

\subsection{Synthesis of the photocatalysts}

$\mathrm{TiO}_{2}$ photocatalytic support was synthesized by sol-gel method. In a glass flask were added the precursors: titanium butoxide (Aldrich 98\%), butyl alcohol (Aldrich 99.4\%) and the hydrolysis catalyst $\mathrm{HNO}_{3}$. The suspension was maintained at $40{ }^{\circ} \mathrm{C}$ for $2 \mathrm{~h}$ in constant stirring. After that, the hydrolysis process was promoted by the slow addition of the calculated amount of distilled water dissolved in $50 \mathrm{~mL}$ of ethanol. The molar ratio of titanium butoxide:water:butyl alcohol used in the material preparation was 1:8:35, respectively. Subsequently, the system was refluxed in stirring at $75^{\circ} \mathrm{C}$ for $24 \mathrm{~h}$. The resulting xerogel was rinsed and dried at 90 ${ }^{\circ} \mathrm{C}$. The material obtained was pulverized and it was calcined at $400{ }^{\circ} \mathrm{C}$ for $6 \mathrm{~h}$. In this study, commercial $\mathrm{Nb}_{2} \mathrm{O}_{5}$ was also used as other photocatalytic support.

The $\mathrm{Ir} / \mathrm{TiO}_{2}$ and $\mathrm{Ir} / \mathrm{Nb}_{2} \mathrm{O}_{5}$ photocatalytic materials were achieved by wet impregnation method from hexachloroiridic acid hexahydrate $\left(\mathrm{H}_{2} \mathrm{IrCl}_{6} \cdot 6 \mathrm{H}_{2} \mathrm{O}\right.$, Sigma Aldrich $99.98 \%$ ) as Ir precursor. The nominal load of iridium was equal to $1.0 \mathrm{wt} \%$. The impregnation of the metal started by the addition of an aqueous suspension of the support $\left(\mathrm{TiO}_{2}\right.$ or $\left.\mathrm{Nb}_{2} \mathrm{O}_{5}\right)$ with the calculated amount of iridium precursor into beaker. The system was maintained in vigorous stirring for $4 \mathrm{~h}$. Then, the material was dried at $90^{\circ} \mathrm{C}$, ground and calcined at $400{ }^{\circ} \mathrm{C}$ for $2 \mathrm{~h}$. The materials were labeled as $\mathrm{Ir} / \mathrm{TiO}_{2}$ and $\mathrm{Ir} / \mathrm{Nb}_{2} \mathrm{O}_{5}$. Finally, the solids were reduced in hydrogen atmosphere at $300^{\circ} \mathrm{C}$ by $2 \mathrm{~h}$.

\subsection{Characterization of the photocatalysts}

The physicochemical properties of the materials were evaluated by the following techniques:

The iridium content was determined by X-ray fluorescence spectroscopy employed a JSX-1000S spectrophotometer equipped with rhodium anode.

Surface area $\left(S_{B E T}\right)$ was estimated by $\mathrm{N}_{2}$ physisorption analysis using a Micromeritics ASAP 2020 instrument. Prior of the analysis, the samples were degassed at $200{ }^{\circ} \mathrm{C}$ for $4 \mathrm{~h}$.
Crystalline phase and crystallite size were determinate by the XRD analysis. The studies were realized using a Bruker D2 Phaser diffractometer with copper $k_{\alpha}$ radiation and a scanning range of $2 \theta=10-80^{\circ}$ and passing of $0.05^{\circ}$.

UV-Vis DRS analysis were realized in order to estimate the band gap energy values. For this purpose, a Varian Cary 100 spectrophotometer equipped with an integration sphere was used. The studies were realized in the region between 200-800 $\mathrm{nm}$. $\mathrm{Ba}_{2} \mathrm{SO}_{4}$ was used as a reference material.

Finally, FTIR studies were carried out using a Thermo Scientific Nicolet iS50 FTIR spectrometer equipped with an ATR accessory. The samples were analyzed en range between 4000 to $400 \mathrm{~cm}^{-1}$, with $8 \mathrm{~cm}^{-1}$ of resolution and 250 scans per sample at room temperature.

\subsection{Photocatalytic degradation of 2,4-diclorophenoxyacetic acid}

The photocatalytic reactions were realized using a homemade pyrex reactor, $200 \mathrm{~mL}$ of a solution of 2,4-D of a concentration of $40 \mathrm{ppm}$ and $100 \mathrm{mg}$ of the photocatalytic material. Initially, the solution and the photocatalyst were added into the reactor and the suspension was maintained in vigorous stirring in absence of irradiation for $30 \mathrm{~min}$, in order to assure the adsorption-desorption equilibrium. Then, the system was irradiated for 210 min with UV light using a Pen-ray lamp with an intensity of 4.4 $\mathrm{mW} / \mathrm{cm}^{2}$ and main wavelength emission of $254 \mathrm{~nm}$, which is protected by a quartz tube and immersed in the solution. The reaction progress was monitored take out an aliquot each $30 \mathrm{~min}$, which were filtered and analyzed using a Cary 100 equip considering the characteristic absorption band of 2,4-D located at $282 \mathrm{~nm}$. Besides, the samples were studied in a TOC- $\mathrm{V}_{C S N}$ analyzer, in order to quantify the content of residual total organic carbon.

\section{Results and discussion}

\subsection{Characterization of the photocatalysts}

The characterization results are summarized in Table 1. The iridium percentage in the materials is slightly higher that the nominal content, which indicates 
the effectiveness of the impregnation process. On the other hand, as can be seen, the sol-gel method used in this work favors the obtaining the materials of $\mathrm{TiO}_{2}$ with a high surface area. However, the impregnation of iridium both in $\mathrm{TiO}_{2}$ and in the commercial support $\mathrm{Nb}_{2} \mathrm{O}_{5}$, causes a decrease in this textural property, which could be a consequence of a possible obstruction of the pores by the metal particles and additional thermal treatments.

Table 1. Characterization results of the tested materials

\begin{tabular}{ccccc}
\hline Photocatalyst & $\begin{array}{c}\text { Ir loading, } \\
\text { wt.\% }\end{array}$ & $\mathbf{S}_{B E T}\left(\mathbf{m}^{2} / \mathbf{g}\right)$ & $\begin{array}{c}\text { Crystallite } \\
\text { Size }(\mathbf{n m})\end{array}$ & $\mathbf{E g}(\mathbf{e V})$ \\
\hline $\mathrm{TiO}_{2}$ & - & 126 & 10 & 3.01 \\
$\mathrm{Ir} / \mathrm{TiO}_{2}$ & 1.06 & 57 & 13 & 2.71 \\
$\mathrm{Nb}_{2} \mathrm{O}_{5}$ & - & 8 & 34 & 3.41 \\
$\mathrm{Ir} / \mathrm{Nb}_{2} \mathrm{O}_{5}$ & 1.09 & 6.5 & 36 & 3.37 \\
\hline
\end{tabular}

The X-ray diffraction patterns are presented in Figure 1. As can be observed, the main signals of the anatase phase of the titanium dioxide located at $2 \theta=25.3^{\circ}, 37.9^{\circ}, 48.1^{\circ}, 53.9^{\circ}, 55.1^{\circ}, 62.8^{\circ}$, $68.8^{\circ}, 70.3^{\circ}$ and $75.1^{\circ}$ (JCPDS-00-001-0562) are identified in the $\mathrm{TiO}_{2}$ support and in the $\mathrm{Ir} / \mathrm{TiO}_{2}$ sample as the anatase phase (Figure 1a). However, the characteristic reflection peaks of iridium is do not evidenced in the diffraction pattern of $\mathrm{Ir} / \mathrm{TiO}_{2}$ sample, which is due to the low content and the probably high dispersion of the metal. Besides, the anatase peaks more intense and sharp observed in $\mathrm{Ir} / \mathrm{TiO}_{2}$ reveal an improvement in the crystallinity and hence the diminution of the specific surface area when compared with the $\mathrm{TiO}_{2}$ support.

On the other hand, Figure $1 \mathrm{~b}$ presents the XRD patterns of the $\mathrm{Nb}_{2} \mathrm{O}_{5}$ support and the $\mathrm{Ir} / \mathrm{Nb}_{2} \mathrm{O}_{5}$ sample. These results evidence the characteristic reflection signals of the hexagonal phase of niobium oxide located at $2 \theta=22.7^{\circ}, 28.6^{\circ}, 36.9^{\circ}, 46.4^{\circ}$, $50.9^{\circ}, 55.5^{\circ}, 56.3^{\circ}, 58.9^{\circ}, 64.1^{\circ}, 71.1^{\circ}$ (JCPDS 00007-0061). As in the case of the iridium material supported on $\mathrm{TiO}_{2}$, the diffraction peaks of the metal were not observed in the $\mathrm{Ir} / \mathrm{Nb}_{2} \mathrm{O}_{5}$ sample due to the low percentage of impregnated metal.

Crystallite size of the materials was calculated using the Debye-Scherrer equation. As can be seen in Table 1, the impregnation of the metal on the
$\mathrm{TiO}_{2}$ and $\mathrm{Nb}_{2} \mathrm{O}_{5}$ supports promotes materials with a higher crystallinity degree and larger crystallite size, which could be associated to the additional thermal treatment.
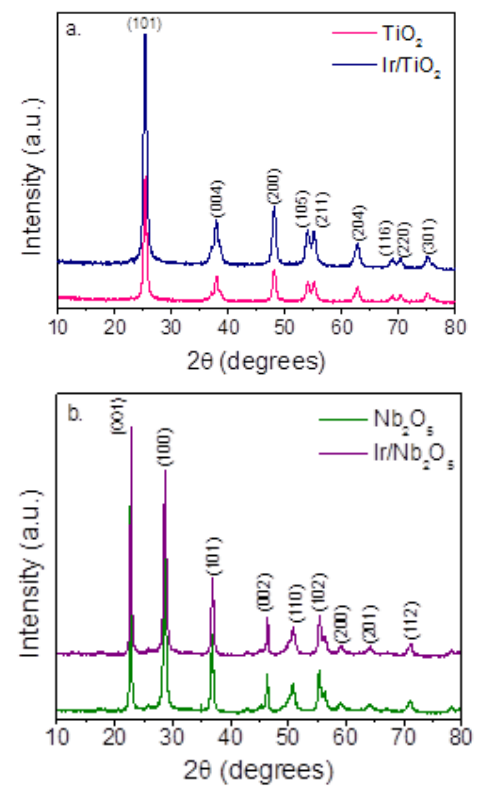

Figure 1. X-ray diffraction patterns of the tested photocatalysts.
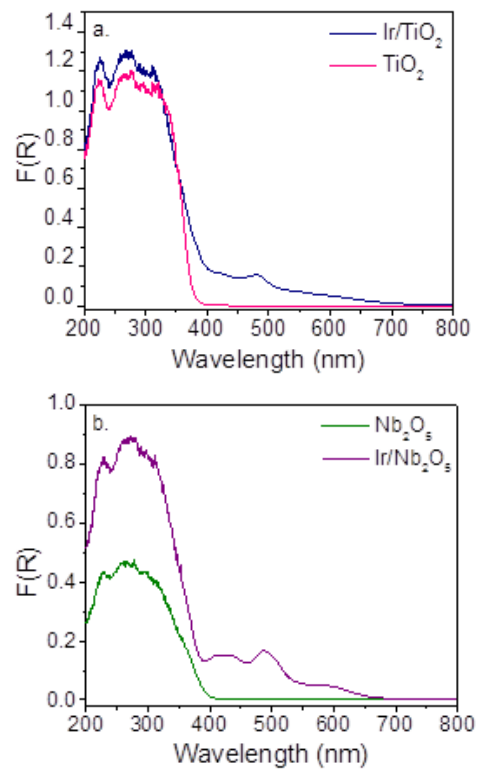

Figure 2. UV-Vis DRS spectra of the tested photocatalysts.

UV-Vis DRS spectra of the tested materials are shown in Figure 2. All the samples present strong absorption in the UV region of the electromagnetic spectrum, which is associated to the intrinsic band 
gap absorption of the semiconductors [27,28]. For $\mathrm{TiO}_{2}$ and $\mathrm{Ir} / \mathrm{TiO}_{2}$ the absorption between 200 and $400 \mathrm{~nm}$ corresponding to the charge transfer from the $\mathrm{O}_{2 p}$ orbitals of the valence band to the $\mathrm{Ti}_{3 d}$ orbitals of the conduction band in the tetrahedral symmetry $[29,30]$. Besides, it was evidenced that the iridium impregnation produces a change in the absorption spectrum of the semiconductor and a weak shoulder is formed near $481 \mathrm{~nm}$, which is due to the presence of an Ir Plasmon band [31].

For the $\mathrm{Nb}_{2} \mathrm{O}_{5}$ and $\mathrm{Ir} / \mathrm{Nb}_{2} \mathrm{O}_{5}$ materials the band in the region of $200-400 \mathrm{~nm}$ is due to the charge transition from oxygen and niobium sites in tetrahedral coordination $[32,33]$. The presence of the metal is manifested by the absorption band in the visible region.

The $E g$ values of the materials were calculated using Kubelka-Munk equation and these are listed in Table 1. As can be seen, the materials of supported iridium present the lower band gap energy values. According the reports of the literature, the displacement toward visible region favors an increase in the rate of the generation of the electronhole pairs on semiconductor surface, which results in an enhanced photoactivity [34].

FTIR spectra of the tested materials are shown in Figure 3. For the $\mathrm{TiO}_{2}$ support and the $\mathrm{Ir} / \mathrm{TiO}_{2}$ sample an intense band below of the $1100 \mathrm{~cm}^{-1}$ is evidenced, which is associated to Ti-O-Ti bridging stretching mode in the crystal [35]. On the other hand, the broad band centered around 3410 $\mathrm{cm}^{-1}$ corresponds to stretching vibration mode of $\mathrm{O}-\mathrm{H}$ bonds of free water molecules and the band centered at $1636 \mathrm{~cm}^{-1}$ is associated to the bending vibration mode of $\mathrm{O}-\mathrm{H}$ bond of chemisorbed water molecules [36].

For the $\mathrm{Nb}_{2} \mathrm{O}_{5}$ support and the $\mathrm{Ir} / \mathrm{Nb}_{2} \mathrm{O}_{5}$ sample the bands located at $627 \mathrm{~cm}^{-1}$ and $841 \mathrm{~cm}^{-1}$ correspond to the stretching vibration of $\mathrm{Nb}-\mathrm{O}-\mathrm{Nb}$ bridging [37] and the $\mathrm{Nb}-\mathrm{O}$ bond, respectively [38]. The band at $1638 \mathrm{~cm}^{-1}$ is associated to bending vibrations of the $\mathrm{O}-\mathrm{H}$ groups [39] and the broad band centered at $3392 \mathrm{~cm}^{-1}$ is related with the stretching vibration of adsorbed water molecules on the surface of the material [40].
In addition, the increased intensity of the bands associated to hydroxyl groups evidenced in the two supported iridium materials indicates highly hydroxylated surfaces [36, 41].
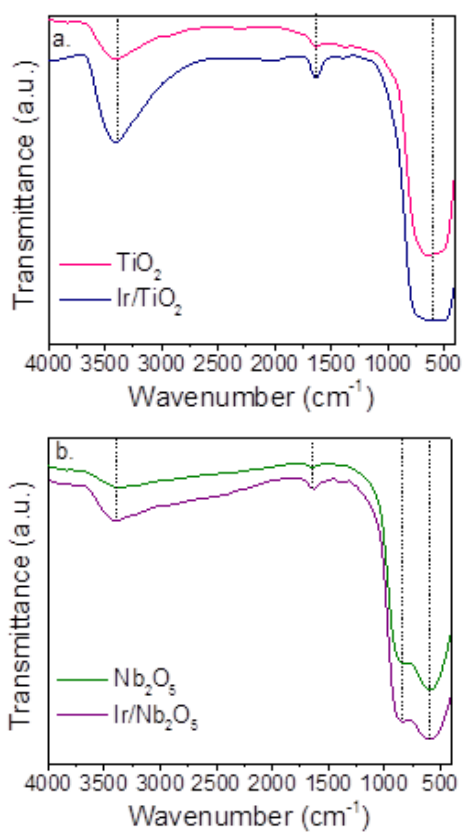

Figure 3. FTIR spectra of the tested photocatalysts.

\subsection{Photocatalytic degradation of 2,4-diclorophenoxyacetic acid}

The effectiveness of the materials was evaluated in the photocatalytic degradation of 2,4-D herbicide under UV radiation. Figure 4 illustrates the UV-Vis absorption spectra obtained using the photocatalytic materials. The bands centered at 203 and $227 \mathrm{~nm}$ correspond to the $\pi \rightarrow \pi^{*}$ transitions of the aromatic ring and the signal at $282 \mathrm{~nm}$ is associated to $n \rightarrow \pi^{*}$ transitions [42]. With the evolution of the reaction a decrease of the intensity of the absorption bands is observed, which suggests the degradation of the herbicide.

In absence of photocatalyst, process known as photolysis, an increase in the absorbance in the range from $240 \mathrm{~nm}$ to $270 \mathrm{~nm}$ of the UV spectrum (Figure 4a) is evidenced, which is associated to the preferential formation of intermediates of reaction [11].

Variation of the relative concentration of herbicide as a time function is presented in Figure 5. In 

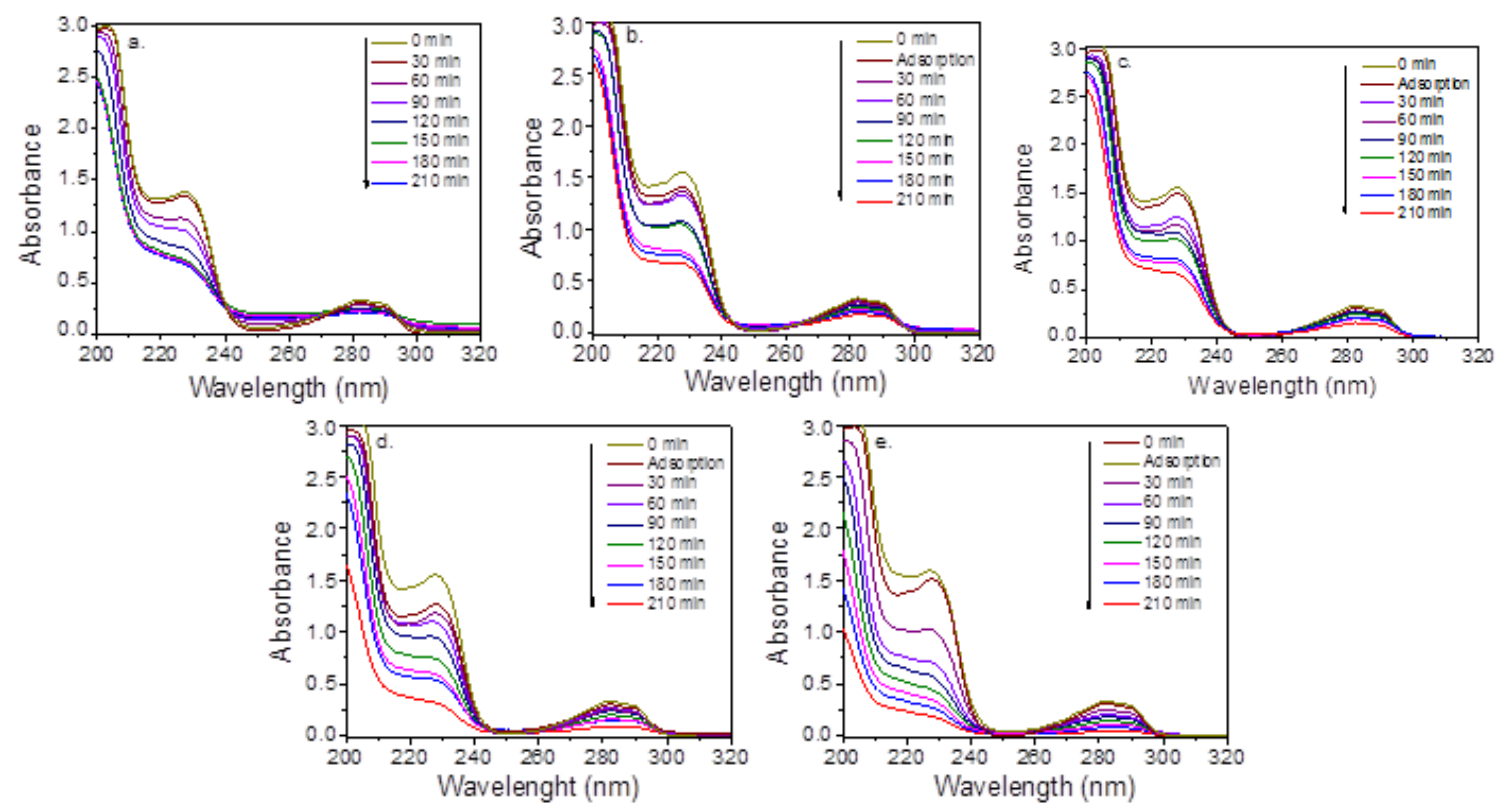

Figure 4. UV-Vis absorption spectra of the photodegradation of 2,4-D: a. Photolysis, b. $\mathrm{Nb}_{2} \mathrm{O}_{5}, \mathrm{c} . \mathrm{Ir}_{2} \mathrm{Nb}_{2} \mathrm{O}_{5}$, d. $\mathrm{TiO}_{2}$ and e. $\mathrm{Ir} / \mathrm{TiO}_{2}$.

absence of photocatalytic material, the degradation of 2,4-D was of $38 \%$, however, the addition of the photocatalytic supports promoted an improvement in the process and a degradation equal to 48 and $72 \%$ were reached using $\mathrm{Nb}_{2} \mathrm{O}_{5}$ and $\mathrm{TiO}_{2}$, respectively. The better photoactivity of the $\mathrm{TiO}_{2}$ support could be result of the higher surface area of this material, which favors the adsorption of more molecules of 2,4-D on the surface.

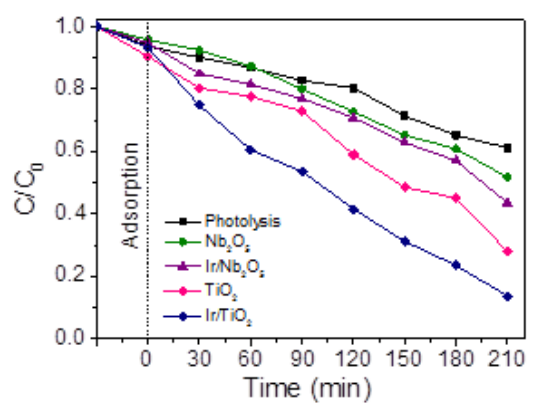

Figure 5. Variation of relative concentration of 2,4-D as a function of reaction time.

In the case of the $\mathrm{Ir} / \mathrm{Nb}_{2} \mathrm{O}_{5}$ and $\mathrm{Ir} / \mathrm{TiO}_{2}$ materials, it is verified that iridium addition lead to reach higher 2,4-D photodegradation that the obtained conducing the reaction in presence of the unmodified semiconductors. Thus, a degradation equal to 57 and $86 \%$ was obtained using $\mathrm{Ir} / \mathrm{Nb}_{2} \mathrm{O}_{5}$ and $\mathrm{Ir} / \mathrm{TiO}_{2}$, respectively. This behavior can be ascribed to the metal acts as an electron collector facilitating the adequate separation of the photogenerated charge carriers and as consequence an enhanced photoactivity is obtained in comparison with the respective supports.

In order to analyze the performance of the tested materials in the mineralization process, total organic carbon studies were realized at $210 \mathrm{~min}$ of reaction and the residual TOC percentages are listed in Table 2. As can be seen, the use of the $\mathrm{Ir} / \mathrm{TiO}_{2}$ photocatalyst favors a higher mineralization of 2,4-D, which confirms the effectiveness of this material for the possible treatment of this type of herbicides.

Table 2. Residual TOC and kinetic parameters for the 2,4-D photocatalytic degradation

\begin{tabular}{ccccc}
\hline Photocatalyst & $\begin{array}{c}\text { \% Residual } \\
\text { TOC }\end{array}$ & $\begin{array}{c}\boldsymbol{k}(\mathbf{x 1 0} \\
\left.\mathbf{m i n}^{-1}\right)\end{array}$ & $\begin{array}{c}\mathbf{t}_{1 / 2} \\
\left(\mathbf{m i n}^{-1}\right)\end{array}$ & $\mathbf{R}^{2}$ \\
\hline $\mathrm{TiO}_{2}$ & 35 & 3.84 & 180 & 0.954 \\
$\mathrm{Ir} / \mathrm{TiO}_{2}$ & 25 & 7.00 & 99 & 0.978 \\
$\mathrm{Nb}_{2} \mathrm{O}_{5}$ & 60 & 2.46 & 282 & 0.967 \\
$\mathrm{Ir} / \mathrm{Nb}_{2} \mathrm{O}_{5}$ & 52 & 2.62 & 265 & 0.982 \\
\hline
\end{tabular}

In addition, from the results of photoactivity, it was determined that de photocatalytic degradation 
of 2,4-D follows a first order kinetics behavior (Figure 6). The values of the rate constant $(k)$, halflife time $\left(t_{1 / 2}\right)$ and correlation coefficient $\mathbf{R}^{2}$ are shown in Table 2.

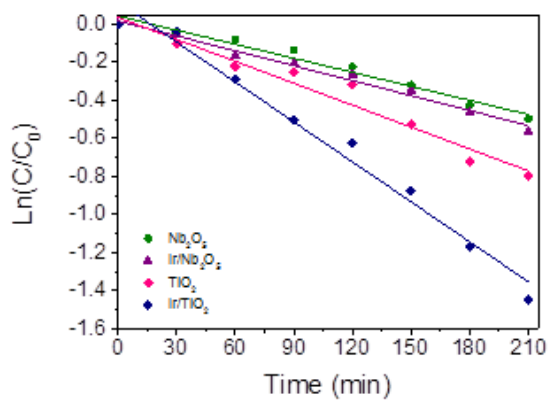

Figure 6. First-order kinetics plots for photocatalytic degradation of 2,4-D.

It is noted that, the highest $k$ and $t_{1 / 2}$ values were reached conducing the reaction with the $\mathrm{Ir} / \mathrm{TiO}_{2}$ photocatalyst, confirming that the material presented a higher photocatalytic activity than the others studied solids. The surface area, the lower band gap energy estimated for $\mathrm{Ir} / \mathrm{TiO}_{2}$ and the role of the metal as electron collector could be the responsible parameters of the best performance of material in the degradation of the herbicide.

Thus, once the $\mathrm{Ir} / \mathrm{TiO}_{2}$ material is irradiated by UV light, the photogenerated electrons on the semiconductor surface migrate from valence band toward conduction band and the frequency of recombination probably is decreased by fast movement of these charge carriers to iridium particles, which act as $e^{-}$collectors. In this conditions, the adequate separation of the $e^{-} / h^{+}$ pairs is achieved and the photogerated holes are available for the effective oxidation of the adsorbed water molecules to produce $\mathrm{OH}$ radicals, main responsible of the degradation of the organic compounds.

\section{Conclusion}

Iridium materials supported on $\mathrm{TiO}_{2}$ and $\mathrm{Nb}_{2} \mathrm{O}_{5}$ supports were obtained using wet impregnation method. The materials were studied in the photocatalytic degradation of 2,4-dichlorophenoxiacetic acid under UV irradiation. The physicochemical characterization evidenced that the addition of the iridium on the evaluated supports cause a decrease of the surface area and energy gap. Besides, it was evidenced that the modification promoted the obtaining of materials with a higher crystallinity degree and with highly hydroxylated surface areas. The photocatalytic activity of the degradation of the herbicide follows the order $\mathrm{Ir} / \mathrm{TiO}_{2}>\mathrm{TiO}_{2}>\mathrm{Ir} / \mathrm{Nb}_{2} \mathrm{O}_{5}>\mathrm{Nb}_{2} \mathrm{O}_{5}$. Thus, it was evidenced that the modification of the supports result in an improvement in the photocatalytic properties of the semiconductors. However, the kinetic constant obtained using the $\mathrm{Ir} / \mathrm{TiO}_{2}$ material was 1.8, 2.8 and 2.7 times greater than the obtained using the $\mathrm{TiO}_{2}$, $\mathrm{Nb}_{2} \mathrm{O}_{5}$ and $\mathrm{Ir} / \mathrm{Nb}_{2} \mathrm{O}_{5}$ materials, respectively. The enhancement in the photocatalytic behavior observed in presence of the $\mathrm{Ir} / \mathrm{TiO}_{2}$ material is assigned to the role of the iridium particles as electron collector, which produces a decrease in the recombination frequency of the charge carriers resulting in an increase in the photoactivity.

\section{References}

[1] J. J. Murcia Mesa, J. A. García, H. Rojas, O. Cárdenas, "Photocatalytic degradation of Phenol, Catechol and Hydroquinone over Au$\mathrm{ZnO}$ nanomaterials", Rev. Fac. de Ing., vol. 94, pp. 24-32, Jan-Mar 2020. http://dx.doi.org/10. 17533/udea.redin.20190513

[2] M. Choquette-Labbé, W. Shewa, J. Lalman, S. Shanmugam, "Photocatalytic Degradation of Phenol and Phenol Derivatives Using a Nano$\mathrm{TiO}_{2}$ Catalyst: Integrating Quantitative and Qualitative Factors Using Response Surface Methodology", Water, vol. 6, pp. 1785-1806, June 2014. https://doi.org/10.3390/w6061785

[3] L. Zaidan, J. Rodríguez, D. Napoleao, M. Branco da Silva, A. Da Nova, M. Benachour, V. Da Silva, "Heterogeneous photocatalytic degradation of phenol and derivatives by $\left(\mathrm{BiPO}_{4} / \mathrm{H}_{2} \mathrm{O}_{2} / \mathrm{UV}\right.$ and $\left.\mathrm{TiO}_{2} / \mathrm{H}_{2} \mathrm{O}_{2} / \mathrm{UV}\right)$ and the evaluation of plant seed toxicity tests", Korean J. Chem. Eng., vol. 34, pp. 511-522, Dec 2017. doi: 10.1007/s11814-016-0293-1

[4] H. Anwer, A. Mahmood, J. Lee, K.H. Kim, J.W. Park, A. Yip, "Photocatalysts for degradation of dyes in industrial effluents: Opportunities 
and challenges", Nano. Res., vol. 12, pp. 955972, Jan 2019. doi: 10.1007/s12274-019-22870

[5] [5] L. Karimi, S. Zohoori, M.E. Yazdanshenas, "Photocatalytic degradation of azo dyes in aqueous solutions under UV irradiation using nanostrontium titanate as the nanophotocatalyst", $J$. Saudi. Chem. Soc., vol. 18, pp. 581-588, Nov 2014. https://doi.org/10.1016/j.jscs.2011.11.0 10

[6] S. Mancipe, J. Martínez, C. Pinzón, H. Rojas, D. Solis, R. Gómez, "Effective photocatalytic degradation of Rhodamine B using tin semiconductors over hydrotalcite-type materials under sunlight driven", Catal. Today., In Press, Dec 2020. https://doi.org/10.1016/j.cattod.2020.12 .014

[7] M. Abdennouri, M. Baalala, A. Galadi, M. El Makhfouk, M. Bensitel, K. Nohair, M. Sadiq, A. Boussaoud, N. Barka, "Photocatalytic degradation of pesticides by titanium dioxide and titanium pillared purified clays", Arab. J. Chem., vol. 9, pp. S313-S318, Sep 2016. https://doi.org/10.1016/j.arabjc.2011.04.005

[8] J. Senthilnathan, L. Philip, "Photodegradation of methyl parathion and dichlorvos from drinking water with $\mathrm{N}$-doped $\mathrm{TiO}_{2}$ under solar radiation", Chem. Eng. J., vol. 172, pp. 678688, Aug 2011. https://doi.org/10.1016/j.cej. 2011.06.035

[9] H. Lee, S. H. Park, Y. K. Park, S. J. Kim, S. G. Seo, S. J. Ki, S. C. Jung, "Photocatalytic reactions of 2,4-dichlorophenoxyacetic acid using a microwave-assisted photocatalysis system", Chem. Eng. J., vol. 278, pp. 259-264, Oct 2015. https://doi.org/10.1016/j.cej.2014.0 9.086

[10] F. X. Nobre, F. A. F. Mariano, F. E. P. Santos, M. L. M. Rocco, L. Manzato, J. M. E. de Matos, P. C. R. Couceiro, W.R. Brito, "Heterogeneous photocatalysis of Tordon 2,4-D herbicide using the phase mixture of $\mathrm{TiO}_{2}$ ", J. Environ. Chem. Eng., vol. 7, pp. 103501, Dec 2019. https: //doi.org/10.1016/j.jece.2019.103501
[11] D. Ova, B. Ovez, "2,4-Dichlorophenoxyacetic acid removal from aqueous solutions via adsorption in the presence of biological contamination", J. Environ. Chem. Eng., vol. 1, pp. 813-821, Dec 2013. https://doi.org/10.1016/j. jece.2013.07.024

[12] R. Kamaraj, D.J. Davidson, G. Sozhan, S. Vasudevan, "Adsorption of 2,4dichlorophenoxyacetic acid (2,4-D) from water by in situ generated metal hydroxides using sacrificial anodes", J. Taiwan Inst.Chem. Eng., vol. 45, pp. 2943-2949, Nov 2014. https://doi.org/10.1016/j.jtice.2014.08.006

[13] M.P Serbent, A. Martínez, A. Pinheiro, A. Giongo, L. Ballod, "Biological agents for 2,4dichlorophenoxyacetic acid herbicide degradation", Appl. Microbiol. Biotechnol., vol. 103, pp. 5065-5078, May 2019. 10.1007/s00253019-09838-4

[14] X. Lü, Q. Zhang, W. Yang, X. Li, L. Zeng, L, Li, "Catalytic ozonation of 2,4dichlorophenoxyacetic acid over novel FeNi/AC", RSC Adv., vol. 5, pp. 10537-10545, Jan 2015. DOI: 10.1039/C4RA11610K.

[15] F. M. de Souza, O. A. A. dos Santos, M.G.A. Vieira, "Adsorption of herbicide 2,4-D from aqueous solution using organo-modified bentonite clay”, Environ. Sci. Pollut. Res., vol. 26, pp. 18329-18342, Apr 2019. 10.1007/s11356019-05196-w.

[16] A. Estrella, M. Asomoza, S. Solís, M.A. García, S. Cipagauta. "Enhanced photocatalytic degradation of the herbicide 2,4-dichlorophenoxyacetic acid by $\mathrm{Pt} / \mathrm{TiO}_{2}$ $\mathrm{SiO}_{2}$ nanocomposites", Reac. Kinet. Mech. Catal., vol. 131, pp. 489-503, Sep 2020. 10.1007/s11144-020-01865-x

[17] S. Neatu, J. Maciá-Agulló, H. Garcia, "Solar Light Photocatalytic $\mathrm{CO}_{2}$ Reduction: General Considerations and Selected Bench-Mark Photocatalysts", Int. J. Mol. Sci., vol. 15, pp. 52465262. Mar 2014. doi: 10.3390/ijms 15045246 
[18] D. Chen, Y. Chen, N. Zhou, P. Chen, Y. Wang, K. Li, S. Huo, P. Chen, P. Peng, R. Zhang, L. Wang, H. Liu, R. Ruan, "Photocatalytic degradation of organic pollutants using $\mathrm{TiO}_{2-}$ based photocatalysts: A review", J. Clean. Prod., vol. 268, pp. 121725, Sep 2020. https: //doi.org/10.1016/j.jclepro.2020.121725

[19] S. Murgolo, S. Franz, H. Arab, M. Bestetti, E. Falletta, G. Mascolo, "Degradation of emerging organic pollutants in wastewater effluents by electrochemical photocatalysis on nanostructured $\mathrm{TiO}_{2}$ meshes", Water Res., vol. 164, pp. 114920, Nov 2019. https://doi.org/10 $.1016 /$ j.watres.2019.114920

[20] S. W. Verbruggen, " $\mathrm{TiO}_{2}$ photocatalysis for the degradation of pollutants in gas phase: From morphological design to plasmonic enhancement", J. Photochem. Photobiol. C: Photochem. vol. 24, pp. 64-82, Sep 2015. https: //doi.org/10.1016/j.jphotochemrev.2015.07.00 1

[21] H. Yu, X. Wang, H. Sun, M. Huo, "Photocatalytic degradation of malathion in aqueous solution using an $\mathrm{Au}-\mathrm{Pd}-\mathrm{TiO}_{2}$ nanotube film", J. Hazard. Mater, vol. 184, pp, 753-758, Dec 2010. https://doi.org/10.1016/j.jhazmat.2010.0 8.103

[22] [22] S. Maddila, S. Rana, R. Pagadala, S.N. Maddila, C. Vasam, S. B. Jonnalagadda, "Ozone-driven photocatalyzed degradation and mineralization of pesticide, Triclopyr by $\mathrm{Au} / \mathrm{TiO}_{2}$ ", J. Environ. Sci. Health B., vol. 50, pp. 571-583, 2015. doi: $10.1080 / 03601234.2015 .1028835$

[23] Y. H. Pai, S. Y. Fang, "Preparation and characterization of porous $\mathrm{Nb}_{2} \mathrm{O}_{5}$ photocatalysts with $\mathrm{CuO}, \mathrm{NiO}$ and $\mathrm{Pt}$ cocatalyst for hydrogen production by light-induced water splitting", $J$. Power. Sources., vol. 230, pp. 321-326, May 2013. https://doi.org/10.1016/j.jpowsour.2012. 12.078

[24] B. Boruah, R. Gupta, J.M. Modak, G. Madras, "Enhanced photocatalysis and bacterial inhibition in $\mathrm{Nb}_{2} \mathrm{O}_{5}$ via versatile doping with met- als ( $\mathrm{Sr}, \mathrm{Y}, \mathrm{Zr}$, and $\mathrm{Ag}$ ): a critical assessment", Nanoscale Adv., vol. 1, pp. 2748-2760, May 2019. doi:10.1039/C9NA00305C

[25] H. Zhang, Q. Lin, S. Ning, Y. Zhou, H. Lin, J. Long, Z. Zhang, X. Wang, "One-step synthesis of mesoporous $\mathrm{Pt}-\mathrm{Nb}_{2} \mathrm{O}_{5}$ nanocomposites with enhanced photocatalytic hydrogen production activity", $R S C A d v$., vol. 6, pp. 96809-96815, Oct 2016. doi: 10.1039/C6RA19118E

[26] M. K. Silva, R. G. Marques, N. R. C. F. Machado, O. A. A. Santos, "Evaluation of $\mathrm{Nb}_{2} \mathrm{O}_{5}$ and $\mathrm{Ag} / \mathrm{Nb}_{2} \mathrm{O}_{5}$ in the photocatalytic degradation of dyes from textile industries", Braz. J. Chem. Eng., vol. 19, pp. 359-363, Dec 2002. https://doi.org/10.1590/S0104-663220 02000400001

[27] X. Cheng, X. Yu, Z. Xing, J. Wan, "Enhanced Photocatalytic Activity of Nitrogen Doped $\mathrm{TiO}_{2}$ Anatase Nano-Particle under Simulated Sunlight Irradiation", Energy Procedia, vol. 16, pp. 598-605, 2012. https://doi.org/10.1016/j.eg ypro.2012.01.096

[28] L. A. Morais, C. Adán, A. S. Araujo, A. Guedes, J. Marugán, "Synthesis, Characterization, and Photonic Efficiency of Novel Photocatalytic Niobium Oxide Materials", Glob. Chall., vol. 1, pp. 1700066, Dec 2017. https: //doi.org/10.1002/gch2.201700066

[29] R. Liu, T. Liu, Y. Qiao, Y. Bie, Y. Song, "Photodegradation of methylene blue over a new down-shifting luminescence catalyst", Bull. Mater. Sci., vol. 42, pp. 239, Jul 2019. https://doi.org/10.1007/s12034-019-1920-3

[30] J. J. Murcia, J. S. Hernández, H. Rojas, J. Moreno-Cascante, P. Sáncehz-Cid, M. C. Hidalgo, J.A. Navío, C. Jaramillo-Páez, "Evaluation of $\mathrm{Au}-\mathrm{ZnO}, \mathrm{ZnO} / \mathrm{Ag}_{2} \mathrm{CO}_{3}$ and $\mathrm{Ag}-\mathrm{TiO}_{2}$ as Photocatalyst for Wastewater Treatment", Top. Catal., vol. 63, pp. 1286-1301, Feb 2020. https://doi.org/10.1007/s11244-020-01232-z

[31] C. Castañeda, I. Alvarado, J. Martínez, M.H. Brijaldo, F. Passos, H. Rojas, "Enhanced photocatalytic reduction of 4-nitrophenol over 
$\mathrm{Ir} / \mathrm{CeO}_{2}$ photocatalysts under UV irradiation", J. Chem. Technol. Biotechnol., vol 94, pp. 2630-2639, May 2019. https://doi.org/10.1 $002 /$ jctb.6072

[32] C. Tiozzo, C. Bisio, F. Carniato, L. Marchese, A. Gallo, N. Ravasio, R. Psaro, M. Guidotti, "Epoxidation with hydrogen peroxide of unsaturated fatty acid methyl esters over $\mathrm{Nb}(\mathrm{V})$-silica catalysts", Eur. J. Lipid Sci. Technol., vol. 115, pp. 86-93, Sep 2013. https://doi.org/10.1002/ej lt. 201200217

[33] C. Tiozzo, C. Bisio, F. Carniato, A. Gallo, S.L. Scott, R. Psaro, M. Guidotti, "Niobium-silica catalysts for the selective epoxidation of cyclic alkenes: the generation of the active site by grafting niobocene dichloride", Phys. Chem. Chem. Phys., vol. 15, pp. 13354-13362, Aug 2013. doi: 10.1039/c3cp51570b

[34] S. Chen, W. Zhao, W. Liu, S. Zhang, "Preparation, characterization and activity evaluation of p-n junction photocatalyst $\mathrm{p}-\mathrm{ZnO} / \mathrm{n}-\mathrm{TiO}_{2}$ ", Appl. Sur. Sci., vol. 255, pp. 2478-2484, Dec 2008. https://doi.org/10.1016/j.apsusc.2008.07 .115

[35] L. M. Ahmed, I. Ivanova, F. H. Husein, D. W. Bahnemann, "Role of Platinum Deposited on $\mathrm{TiO}_{2}$ in Photocatalytic Methanol Oxidation and Dehydrogenation Reactions", Int. J. Photoenergy, vol. 2014, pp. 1-9, Feb 2014. https://doi.org/10.1155/2014/503516

[36] [36] K. M. Rahulan, S. Ganesan, P. Aruna, "Synthesis and optical limiting studies of Audoped $\mathrm{TiO}_{2}$ nanoparticles", Adv. Nat. Sci.: Nanosci. Nanotechnol., vol. 2, pp. 1-7, May 2011. doi:10.1088/2043-6262/2/2/025012

[37] N. Rani, R. Ahlawat, "Structural and optical properties of $\mathrm{Nb}_{2} \mathrm{O}_{5} / \mathrm{SiO}_{2}$ powder prepared by sol-gel method", AIP. Conf. Proc., vol. 2265, pp. 1-5, Nov 2020. https://doi.org/10.1063/5. 0017030

[38] C. Daza, J. Rodríguez, "The effect of the synthesis conditions on structure and photocatalytic activity of $\mathrm{Nb}_{2} \mathrm{O}_{5}$ nanostructures", Process. Appl. Ceram., vol. 12, pp. 218-229, Aug 2018. https://doi.org/10.2298/PAC1803218G

[39] G. Ma, K. Li, Y. Li, B. Gao, T. Ding, Q. Zhong, J. Su, L. Gong, J. Chen, L. Yuan, B. Hu, J. Zhou, K. Huo, "High-Performance Hybrid Supercapacitor Based on Graphene-Wrapped Mesoporous $\mathrm{T}-\mathrm{Nb}_{2} \mathrm{O}_{5}$ Nanospheres Anode and Mesoporous Carbon-Coated Graphene Cathode", Chem. Electro. Chem., vol. 3, pp. 1360-1368, Jun 2016. https://doi.org/10.1002/ celc. 201600181

[40] L. R. V. da Conceição, L. M. Carneiro, J.D. Rivaldi, H.F. de Castro, "Solid acid as catalyst for biodiesel production via simultaneous esterification and transesterification of macaw palm oil", Ind. Crops. Prod., vol. 89, pp. 416424, Oct 2016. https://doi.org/10.1016/j.indcro p.2016.05.044

[41] M. Hamadanian, A. Reisi-Vanani, A. Majedi, "Sol-gel preparation and characterization of $\mathrm{Co} / \mathrm{TiO}_{2}$ nanoparticles: Application to the degradation of methyl orange", J. Iranian Chem. Soc., vol. 7, pp. S52-S58, Jul 2010. https://doi.org/10.1007/BF03246184

[42] M. Crocker, U. M. Graham, R. Gonzalez, G. Jacobs, E. Morris, A. M. Rubel, R. Andrews, "Preparation and characterization of cerium oxide templated from activated carbon", $J$. Mat. Sci., vol. 42, pp. 3454-3464, Jan 2007. https://doi.org/10.1007/s10853-006-0829-6 